\title{
Comparison by Sequence-Based and Electron Microscopic Analyses of Fig mosaic virus Isolates Obtained from Field and Experimentally Inoculated Fig Plants
}

\author{
Kadriye Çağlayan, Çiğdem Ulubaş Serçe, Eminur Barutçu, and Kamuran Kaya, Mustafa Kemal University, \\ Agriculture Faculty, Plant Protection Department, 31034 Antakya-Hatay, Turkey; Vicente Medina, Lleida Univer- \\ sity, Department of Producció Vegetali Ciència Forestal Lleida, Spain; Mona Gazel and Soner Soylu, Mustafa Ke- \\ mal University, Agriculture Faculty, Plant Protection Department, 31034 Antakya-Hatay, Turkey; and Oğuzhan \\ Çalışkan, Mustafa Kemal University, Agriculture Faculty, Horticulture Department, 31034 Antakya-Hatay, Turkey
}

\begin{abstract}
Çağlayan, K., Serçe, Ç. U., Barutçu, E., Kaya, K., Medina, V., Gazel, M., Soylu, S., and Çalışkan, O. 2010. Comparison by sequence-based and electron microscopic analyses of Fig mosaic virus isolates obtained from field and experimentally inoculated fig plants. Plant Dis. 94:14481452 .

Fig mosaic disease (FMD) and the fig mite, Aceria ficus, are widespread in different fig growing provinces of Turkey. Fig trees (Ficus carica) cv. Bursa siyahı (D1) and an unknown seedling (D2) that showed typical FMD symptoms and was heavily infested by fig mites were used as donor plants for attempted mite transmissions to healthy fig seedlings. Transmission electron microscopy observations of donor plant samples prior to the transmission tests were performed and showed the presence of double membrane bodies (DMBs) in the palisade mesophyll cells. Electron microscopy of all experimentally inoculated fig seedlings showed the same bodies. This result reinforced the suggestion that an agent that elicits the production of DMBs in infected cells is involved in the etiology of FMD. Double-stranded (ds)RNA analyses were also performed from experimentally inoculated plants, and dsRNAs with sizes approximately 1.30 and $1.96 \mathrm{~kb}$ were obtained. Reverse transcription-polymerase chain reaction (RT-PCR) products of 468 and 298 bp specific to Fig mosaic virus (FMV) were amplified from both donor and experimentally inoculated plants. BLAST analyses of nucleotide sequences of these fragments showed $90 \%$ identity with FMV for the donor plant and 94 to $96 \%$ for experimentally inoculated plants. According to these results, FMV is present in both donor and experimentally inoculated plants in Turkey, and this virus is transmissible by A. ficus from fig plant to fig plant.
\end{abstract}

The fig mosaic disease (FMD), which was described first by Condit and Horne (7), is a widespread disease in fig-growing countries. Affected plants showed mosaic and different patterns including chlorotic spots, leaf discoloration, and various types of leaf and fruit deformations. The causal agent of FMD has remained unidentified, but recently several distinct viruses have been reported from fig trees showing typical FMD symptoms. These include Fig leaf mottle-associated virus 1 and 2 (FLMaV1 and FLMaV2), tentative members of the family Closteroviridae $(10,11)$; Fig latent virus-1 (FLV-1), a new member of the genus Trichovirus of the family Flexiviridae (14); a virus that has a multipartite, negative-sense single-stranded (ss)RNA called Fig mosaic-associated

Corresponding author: Kadriye Çağlayan

E-mail: kcaglayano@yahoo.com

Accession numbers: GU227408 to GU227423, GU565156, and GU565157.

Accepted for publication 28 June 2010.

doi:10.1094/PDIS-11-09-0771

(C) 2010 The American Phytopathological Society virus (FMaV) (29), and Fig mosaic virus (FMV), which belongs to the recently proposed genus Emaravirus of the family Bunyaviridae $(9,12)$. Analysis of complete nucleotide sequences of four viral RNA segments of FMV revealed that putative nucleocapsid proteins encoded by RNA-3 have homology with comparable sequences of European mountain ash ringspot-associated virus (EMARaV) and the unclassified viruses Pigeon pea sterility mosaic virus (PPSMV) and Wheat mosaic virus (the causal agent of High Plains disease) (12).

The pathogen(s) causing FMD can be transmitted by vegetative propagation of infected cuttings and by an eriophyid mite, Aceria ficus Cotte (13), but not by seed (7). FMD can be serious on leaves and fruits, especially if FMD and A. ficus are present together (3). A. ficus, also called the ficus mottle mite, is a worldwide pest of figs, and it has been recorded from different provinces of Turkey where fig production is economically important $(15,24)$.

The pest is highly host specific and mainly restricted to species of the genus Ficus. All life stages were found throughout the year, but it appears that the pathogen(s) causing FMD is not transmitted through the egg of A. ficus (23). Little is known about the transmission efficiency of the FMD agents by A. ficus. The transmission properties and the occurrence of double membrane-bound bodies (DMBs) in FMD-affected plant tissues closely resembles characteristics of other diseases, e.g., sterility mosaic (18), High Plains (2), rose rosette (16), thistle mosaic (2), wheat spot chlorosis (4), and yellow ring spot of redbud (17), where the etiological agent has not been demonstrated yet.

All studies so far suggest that fig trees have a complex of viruses associated with them. However, agents causing FMD that are efficiently transmitted by A. ficus remain unknown. In this article, we show efficient eriophyid mite transmission of a virus capable of causing FMD, and show nucleotide sequence and cytopathological characteristics associated with FMV. A brief abstract of this study was recently published (6).

\section{MATERIALS AND METHODS}

Plant materials. Fig plants cv. Bursa siyahı (D1) and an unknown seedling (D2) that were heavily infested by A. ficus and showed characteristic FMD symptoms, growing at Mustafa Kemal University collection orchard (MKUCO) in Hatay Province, Turkey, were used as FMD and eriophyid mite sources (donor plants) for all transmission experiments. FMD infection was identified by symptoms and verified by transmission electron microscopic (TEM) observations.

Fruits of D1 and D2 plants were obtained from nonsymptomatic fig trees in MKUCO. Fruit flesh was removed; seeds were washed with tap water and soaked in $10 \mathrm{ml}$ of Captan solution $(0.5 \mathrm{~g} / \mathrm{liter})$ for $10 \mathrm{~min}$. Seeds were placed in 11-mmdiameter petri dishes containing a double layer of wet filter paper and kept in the dark at $25^{\circ} \mathrm{C}$ for 6 weeks for germination. Germinated seeds were first transplanted into trays and then when roots were fully developed, transplanted into $15-\mathrm{cm}$ pots. All plants were maintained in growth rooms at $25^{\circ} \mathrm{C}$ for a $16-\mathrm{h}$ day and an 8 -h night at $20^{\circ} \mathrm{C}$, with a $70 \%$ constant relative humidity.

Transmission experiments. Eriophyid mite infested leaves from donor plants 
were maintained at $+4^{\circ} \mathrm{C}$ before using for transmission experiments. These fig leaves were examined under a stereobinocular microscope, and leaf pieces having eight eriophyid mites were cut and their lower surfaces manually transferred to the upper surface of one leaf of young, healthy fig seedlings at the three- to four-leaf stage. Leaf pieces including eight $A$. ficus were fixed to healthy fig plants using a very thin pin. This experiment was replicated 10 times for each donor plant. Five noninoculated seedlings of both D1 and D2 plants served as healthy controls. Five randomly selected seedlings from each donor plant were examined by TEM before inoculation. A. ficus was kindly identified by Prof. Sabahat Sullivan (OMU Plant Protection Department, Samsun, Turkey). Inoculated plants were maintained at the laboratory for 1 day and then placed in a growth room at $25^{\circ} \mathrm{C}$ for a 16 -h day and at $20^{\circ} \mathrm{C}$ for an 8 -h night as above, with $70 \%$ constant relative humidity.

Two subcultures were made from the symptomatic test plants by manually transferring the disease from the first symptomatic leaf using eriophyid mites to a new test plant. Numbers of A. ficus were not counted during the subculturing process. All test plants were sprayed with Hexythiazox ( $50 \mathrm{ml} / 100$ liters) after the first symptom appearance and sample collection for subculturing process. The plants were maintained in growth rooms as described above. Transmission experiments were conducted in July when the mite population was high for Hatay province located in the Eastern Mediterranean Region of Turkey.

TEM. Samples for TEM were excised from leaves of the donor plants and experimentally inoculated fig seedlings, fixed immediately in a solution of $3 \%$ glutaraldehyde in $50 \mathrm{mM}$ phosphate buffer $(\mathrm{pH}$ 7.2 ), and kept overnight at $+4^{\circ} \mathrm{C}$. The samples were then washed in the same buffer and postfixed in $1 \%$ osmium tetroxide $\left(\mathrm{OsO}_{4}\right)$ in the same buffer for $2 \mathrm{~h}$ at room temperature. Following osmium tetroxide fixation, the samples were dehydrated in a graded series of increasing acetone concentrations. Dehydrated samples were subsequently embedded in an Epon araldite mixture as described earlier $(20,26)$. Ultrathin sections (70 to $90 \mathrm{~nm}$ ) were cut with an Ultracut E microtome (Reichert, Milton Keynes, UK) using glass or diamond knives (Diatome, Bienne, Switzerland). The sections were then routinely mounted for staining on Formvar-coated 200 mesh copper grids (Aldrich, Dorset, UK). Grid-mounted sections with silvergold interference color were stained in drops of $4.5 \%$ uranyl acetate. After treatment, grids were washed in distilled water and further stained in drops of Reynold's lead citrate (25). All sections were viewed using Zeiss-910 TEM at an accelerating voltage of $75 \mathrm{kV}$.
Extraction of double-stranded (ds)RNA. Leaves and bark scrapings from experimentally inoculated fig seedlings and healthy fig plants were used for dsRNA extraction. Tissue samples $(30 \mathrm{~g})$ were ground in liquid nitrogen, and dsRNAs were recovered using 2 cycles of CF-11 (Whatman, Springfield Mill, England) column chromatography followed by ethanol precipitation (29). The dsRNA pellets were dissolved in $12 \mu \mathrm{TE}$ buffer (10 mM Tris, pH 7.4, $1 \mathrm{mM}$ EDTA, pH 8.0) and subjected to electrophoresis in a $2 \%$ agarose gel, stained with ethidium bromide, and visualized under UV light.

Extraction of total RNA, reverse transcription-polymerase chain reaction (RT-PCR), and nucleotide sequence analysis. Total RNAs were extracted from donor plants and used to experimentally inoculate fig seedlings using RNeasy Plant mini kit (Qiagen, GmbH, Germany) following the manufacturer's instructions. Seven different published specific primer pairs related to FMD were used for RTPCR analyses: Fig leaf mottle-associated virus 1 and 2 (FLMaV1 and FLMaV2) (accession nos. AM279677 to AM286422) $(11,12)$, closest homologs of Carrot red leaf luteovirus associated RNA (CRLaRNA, specific for RdRp) (accession no. FJ211075), Carrot mottle mimic virus (CMMV, specific for RdRp) (Acc. No: FJ211076); Strawberry chlorotic fleck associated virus (SCFaV, Closterovirus, specific for Replicase) (accession no. FJ211077); Fig mosaic associated virus (previously defined as European mountain ash ringspot-associated virus-like [EMARaV-like]) specific for nucleocapsid (NP) (accession no. FJ211073) and glycoprotein regions (GP) (accession no. FJ211074) (29). Positive control samples (FMaV-Californian isolate) were kindly supplied by Bryce Falk, USDA/USA). Asymptomatic fig seedlings were used as negative control.

A one-step RT-PCR protocol was used in a $25-\mu$ reaction volume containing $1 \times$ RT-PCR buffer, $1.1 \mathrm{mM} \mathrm{MgCl}_{2}, 5 \mathrm{mM}$ dithiothreitol (DTT), $0.2 \mathrm{mM}$ dNTPs, 0.5 $\mu \mathrm{M}$ of each primer, $1.25 \mathrm{U}$ of Taq polymerase (Fermentas, GmbH, Germany), and $20 \mathrm{U}$ of Moloney-Murine Leukemia Virus
(M-MLV) reverse transcriptase (Fermentas). Reactions were performed at $42^{\circ} \mathrm{C}$ for $30 \mathrm{~min}$ (reverse transcription), $94^{\circ} \mathrm{C}$ for 30 $\mathrm{s}, 54^{\circ} \mathrm{C}$ for $45 \mathrm{~s}\left(56^{\circ} \mathrm{C}\right.$ for $30 \mathrm{~s}$ for FLMaV1 and FLMaV2), $72^{\circ} \mathrm{C}$ for $1 \mathrm{~min}$ for 35 cycles; and a final extension for 10 min at $72^{\circ} \mathrm{C}$. RT-PCR products were analyzed by $1.5 \%$ agarose gel electrophoresis and ethidium bromide staining.

All RT-PCR products were directly sequenced from both directions. Sequencing was performed using an AB1373 Automated Sequencer at Iontek (Istanbul, Turkey). Nucleotide sequences of primers were removed, and the sequences have been deposited in the GenBank database under the GU227408 to GU227423 accession numbers. Multiple alignments of the nucleotide sequences determined in this work with sequences related to FMD available in the international databanks were performed using the default options of Clustal X 1.8, a Windows interface of the Clustal W multiple sequence alignment program (28). The alignments were used to reconstruct phylogenetic trees using the neighbor-joining method with nucleotide identity distances, using the PAUP program (27). Bootstrap analyses with 1,000 replicates were performed to estimate the support for inferred phylogenies.

\section{RESULTS}

Field and EM observations of donor plants. The most common symptoms observed on leaves and fruits of donor plants were distinctly yellow mosaic spots, contrasting with normal green color of the foliage. Deformed leaves sometimes occurred on the same twig with normal leaves. The strongest symptoms were observed on D1 followed by D2 (Fig. 1).

Ultrastructural studies performed by TEM showed that DMBs were 100 to 220 $\mathrm{nm}$ in size and were mainly observed in parenchyma and mesophyll cells of infected leaves of D1 (Fig. 2A) and D2 (Fig. 2B) donor plants.

Symptoms and EM observations of experimentally inoculated fig seedlings. Experimentally inoculated fig seedlings showed atypical mosaic symptoms and leaf deformation in 10 to 20 days following eriophyid mite transmission (Fig. 3).

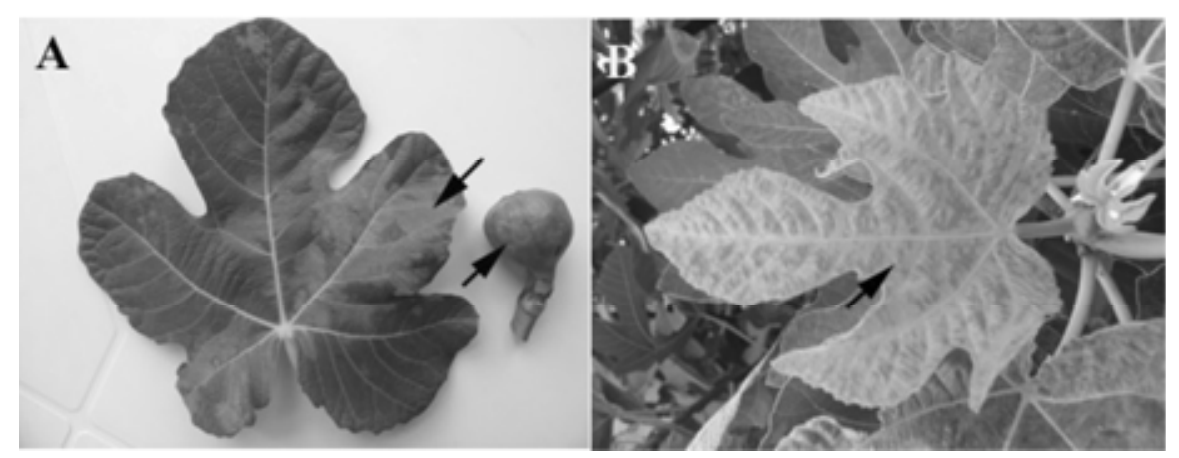

Fig. 1. Fig mosaic disease symptoms on $\mathbf{A}$, leaf and fruit of donor plant D1 and $\mathbf{B}$, leaf of donor plant D2. 
When the first symptomatic leaves of experimentally inoculated fig seedlings including eriophyid mites were transferred to new healthy seedlings for subculturing, similar symptoms on the subcultured plants were observed at the same duration. To verify symptom observations, the tissues of experimentally inoculated and healthy control fig plants were examined by TEM. DMBs that were very similar to the ones in donor plants were abundantly present in the mesophyll cells of experimentally inoculated plant tissues (Fig. $2 \mathrm{C}$ ), whereas no similar bodies were observed in healthy control plant tissues. Due to their presence in both donor plants and experimentally inoculated fig seedlings, and their absence in healthy control plants, we believe that it is very likely that DMBs are involved in the etiology of FMD.

dsRNA analyses. Different dsRNAs, with sizes ranging from 1.3 to $c a .2 \mathrm{~kb}$, were obtained from experimentally inocu- lated fig seedling (Fig. 4). Repeated electrophoretic analyses from healthy and experimentally inoculated seedlings consistently yielded dsRNAs of $c a .1 .3,1.5$, 1.8 , and $1.96 \mathrm{~kb}$. Two dsRNAs (1.3 and $1.96 \mathrm{~kb})$ were present only in experimentally inoculated plants but not in healthy controls. This suggested RNA virus incidence in experimentally inoculated fig plants.

RT-PCR and nucleotide sequence analysis. RT-PCR amplifications using seven different published specific primer pairs related to FMD resulted in an ampli-



Fig. 3. A and B, Mosaic symptoms on fig seedlings experimentally inoculated by Aceria ficus (arrows); mite-free control plant (asterisk) is typically symptomless.

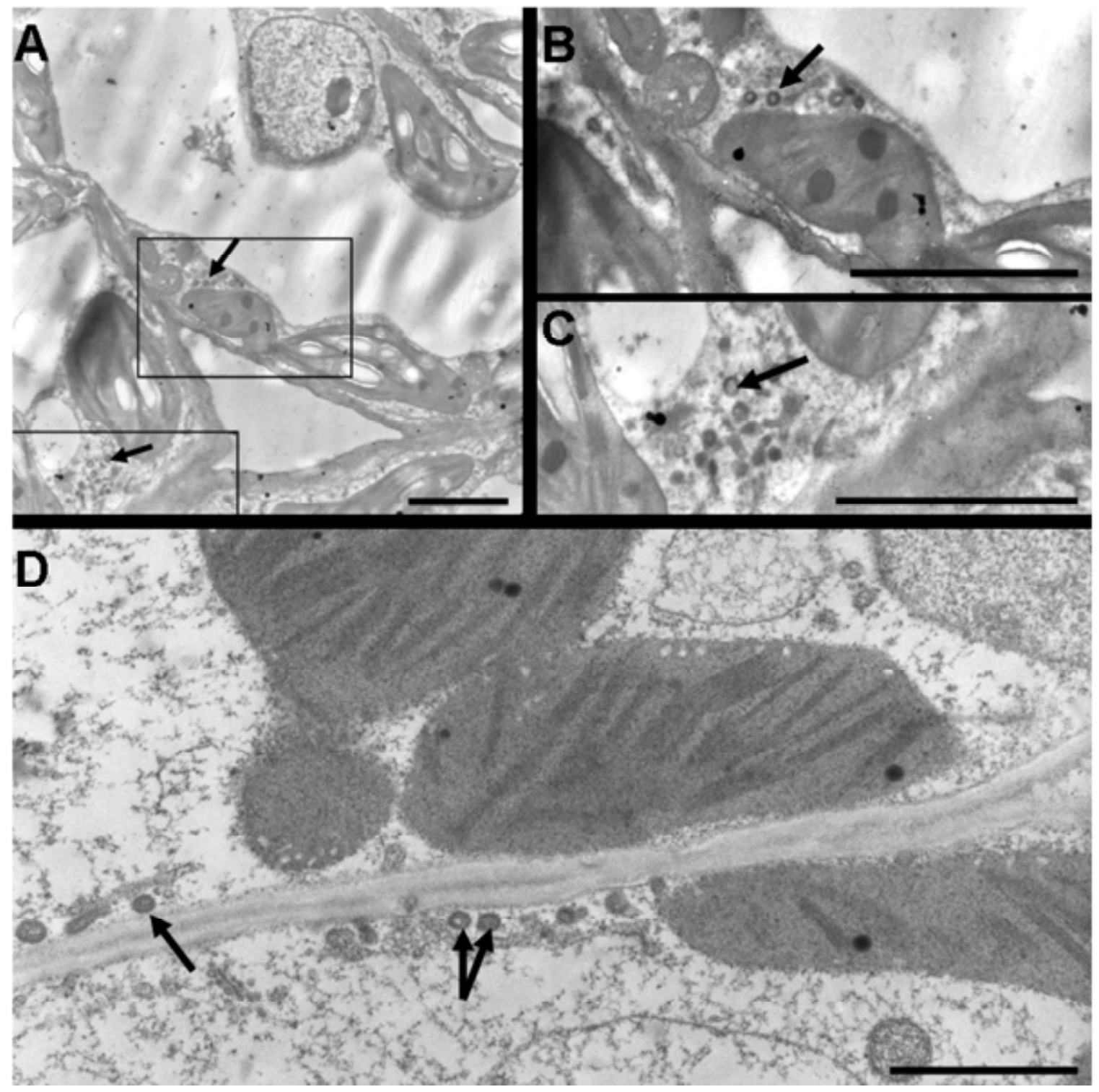

Fig. 2. Typical double membrane bodies (DMBs, arrows) associated with fig mosaic disease in A to C, donor fig plant D1. B and C are details of A. D, Experimentally inoculated fig seedling. $\mathrm{ch}=$ chloroplast. A to $\mathrm{C}, \mathrm{Bars}=2.3 \mu \mathrm{m}, \mathrm{D}, \mathrm{bar}=1.3 \mu \mathrm{m}$. 
con of 468 bp specific for the FMaV-GP region and an amplicon of $298 \mathrm{bp}$ specific for the FMaV-NP region. These amplicons were obtained from both donor plants (D1 and D2) and 10 of the experimentally inoculated plants (Fig. 5). No amplicons resulted by RT-PCR using the other primers. BLAST analysis of nucleotide sequences of two donor plants (D1 and D2) and seven experimentally inoculated plants (experimentally inoculated plants from D1: EI-D1-3, EI-D1-6, EI-D1-7, EI-D1-9, EIBS-15; experimentally inoculated plants from D2: EI-D2-18, EI-D2-R2) showed homology with FMaV and FMV. Comparisons of the fragment sequences from the donor plants and experimentally inoculated seedlings with those from FMaV and FMV in GenBank indicated close affinities among the isolates, identity ranging from 83 to $99 \%$ for the FMaV-GP region and from 85 to $100 \%$ for FMaV-NP region. This analysis is confirmed by the phylogenetic tree showing that all sequences of the FMaV-GP region of donor plant D1 and experimentally inoculated fig seedlings from this donor had a distinct cluster separate from donor plant D2 and experimentally inoculated fig seedlings from this donor, and was supported by high bootstrap values (Fig. 6).

\section{DISCUSSION}

The present investigation shows that both donor fig trees and fig seedlings ex-



Fig. 4. Electrophoretic pattern of doublestranded (ds)RNA extracted from healthy fig seedling $(\mathrm{H})$ and experimentally inoculated fig seedling (EI-D2-R2). M: DNA molecular marker ( $\lambda E c o$ RI + HindIII) DNA ladder. Different patterns of dsRNA from healthy plant as indicated by arrows $\mathrm{A}$ and $\mathrm{B}$. perimentally inoculated by A. ficus can harbor DMBs and FMV according to the results of EM observations and molecular analyses (RT-PCR and sequencing), respectively. Association of DMBs with FMD originally was observed by Bradfute et al. (4) and later described by Martelli et al. (19) and Serrano et al. (26). Although the presence of DMBs in field-infected symptomatic fig plants has recently been reported $(5,6)$, results of the present investigation are the first record of DMBs in experimentally inoculated fig seedlings in Turkey. Similar results have been recently obtained by Elbeaino et al. $(9,12)$, and they have shown that FMV was transmitted by A. ficus to healthy fig seedlings, which developed chlorotic ringspots that expanded into a mosaic pattern. Because feeding injury by A. ficus causes early symptoms that could be easily confused with symptoms of FMD (13), disease symptoms should be well differentiated. In addition to transmitting FMD agents, $A$. ficus caused epidermal cell death as previously reported by Baker (3). Ebeling and Pence (8) recognized that feeding injury by A. ficus causes leaf distortion, chlorosis, scarring and russeting of the eye scales, stunting, and immature leaf drop, most of which are common symptoms for FMD. Thus, it is important to confirm the agent(s) that causes the disease symptoms on figs. The dsRNAs, with sizes ranging from 0.6 to $7 \mathrm{~kb}$, were identified in Portugal, Turkey, California, and Italy from mosaic-diseased figs $(1,12,22,29)$. FMaV genomic segments 2 and 3 are $\sim 2.1$ and $\sim 1.8 \mathrm{~kb}$, respectively (29). FMV four genomic segments are $\sim 7 \mathrm{~kb}, \sim 2.2 \mathrm{~kb}, \sim 1.5$ $\mathrm{kb}$, and $\sim 1.4 \mathrm{~kb}$, respectively (12). The larger dsRNA $(1.96 \mathrm{~kb})$ obtained in this study was similar to FMaV in California, and the smaller $(1.3 \mathrm{~kb})$ was very similar to the smallest genomic segment of FMV in Italy.

Recently, complete sequences of four viral single-stranded, negative sense RNA segments of the putative Fig mosaic virus
(FMV) have been determined by Elbeaino et al (9). These sequences have a close phylogenetic relationship with RNAs of EMARaV (21). Similar sequences have been identified in $96 \%$ of mosaicaffected figs from a Californian germplasm collection and are called FMaV (29). In the present investigation, the same virus was confirmed both in field infected (donor) plants and in experimentally inoculated plants, assuming that DMBs and FMV are significantly involved in the etiology of FMD.

Although closterovirus-like viruses were commonly present in the USDA fig germplasm collection, almost all fig samples collected from the field were infected with the EMARaV-like virus, suggesting that the closterovirus is not the causal agent of FMD (29). Similarly, a closterovirus named FLMaV 1 and 2 was associated with symptomatic and asymptomatic fig trees (11). In the present investigation, RTPCR amplifications performed with primer pairs specific for members of the genera Closterovirus, Luteovirus, Umbravirus, and Emaravirus indicated that donor plants and experimentally inoculated seedlings only harbored FMaV, which supports previous data. Nucleotide sequences of FMaV-GP and -NP regions obtained from donor fig plants and experimentally inoculated fig seedlings showed only homology with FMaV and FMV. Cluster analyses showed that FMaV-GP nucleotide sequences of donor plants placed in two different clusters with high bootstrap value and all sequenced fragments of experimentally inoculated seedlings consistently grouped together with their own donors (Fig. 6). This indicates that Turkish FMV isolates might have genetic variation in different cultivars. Based on nucleotide sequence-based phylogenetic association and previously reported properties, FMD in field and experimentally inoculated plants from Turkey is caused by the newly described Fig mosaic virus (FMV).

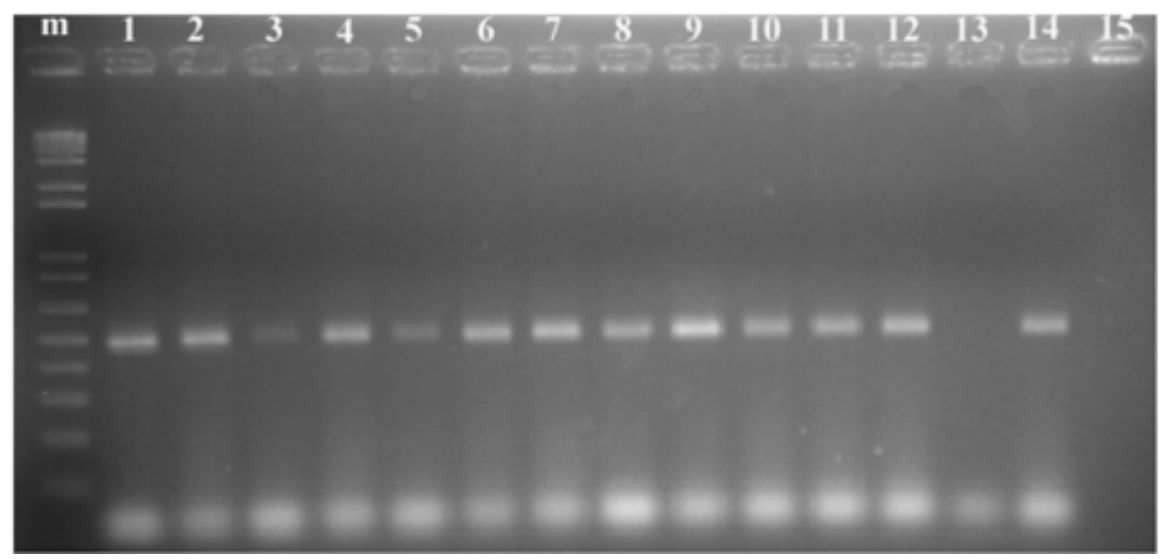

Fig. 5. Gel electrophoresis of reverse transcription-polymerase chain reaction (RT-PCR) products amplified with Fig mosaic virus primer pair specific to glycoprotein coding region. Lane 1: donor plant D1; lane 2: donor plant D2; lanes 3 to 12: experimentally inoculated fig plants; lane 13: healthy control (fig seedling); lane 14: positive control (FMaV-Californian isolate), lane 15: water control. 
A

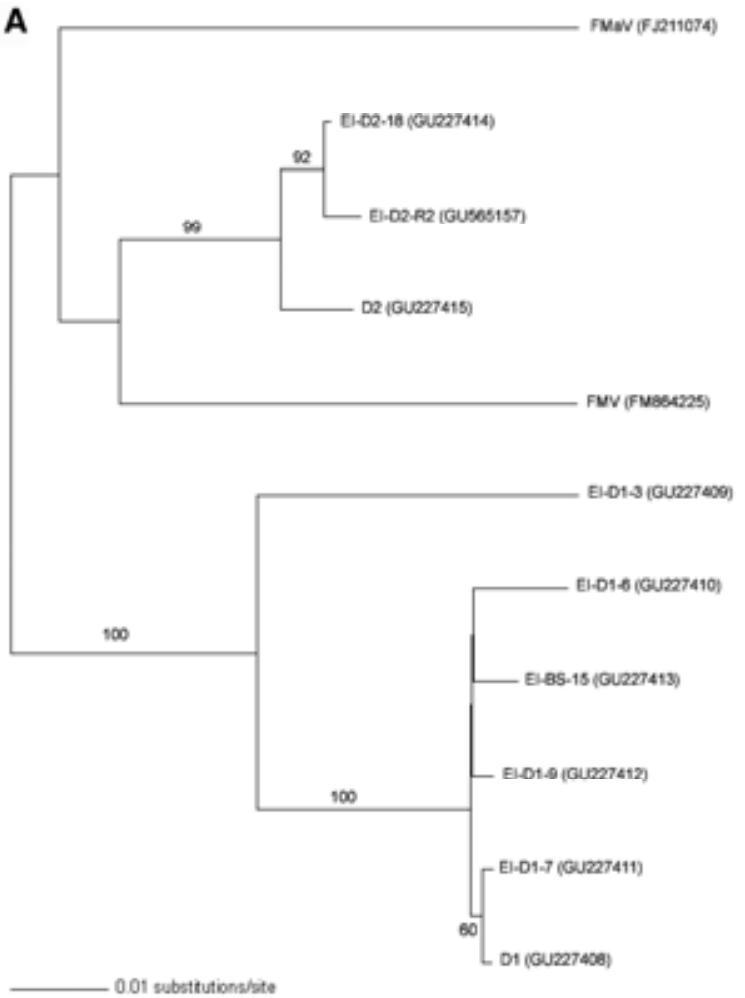

B

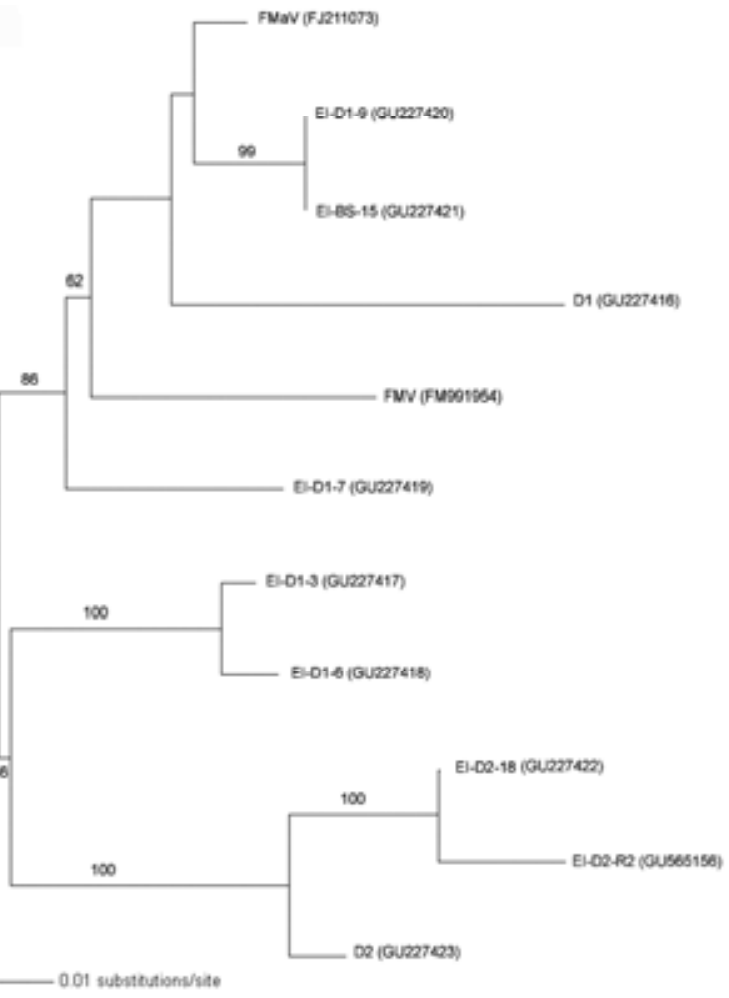

Fig. 6. Phylogenetic trees reconstructed using partial A, glycoprotein and $\mathbf{B}$, nucleoprotein genomic sequences of Fig mosaic virus (FMV) from donor plants (D1, D2) and experimentally inoculated (EI) fig seedlings. The numbers near nodes represent the percentages determined by bootstrap analysis with 1,000 replicates. Only bootstrap values above 50\% are shown. Accession numbers of viral sequences are reported within parentheses.

\section{ACKNOWLEDGMENTS}

The authors thank Bryce W. Falk for his critical reading of the manuscript. This study was supported by a grant (number TÜBİTAK-TOAG106O134) from the Scientific and Technological Research Council of Turkey.

\section{LITERATURE CITED}

1. Açikgöz, S., and Döken, M. T. 2003. Determination of sampling time for dsRNA isolation of the agent of fig mosaic disease prevalence in Aegean region-Turkey. Acta Hortic. 605:307-310.

2. Ahn, K. K., Kim, K. S., Gergerich, R. C., Jensen, S. G., and Anderson, E. J. 1996. Comparative ultrastructure of double membranebound particles and inclusions associated with eriophyid mite-borne plant diseases of unknown etiology: A potential new group of plant viruses. J. Submicrosc. Cytol. Pathol. 28:345355.

3. Baker, E. W. 1939. The fig mite Eriophyes ficus Cotte and other mites of the fig tree (Ficus carica L.). Bull. Calif. Dep. Agric. 28:266-275.

4. Bradfute, O. E., Whitmoyer, R. E., and Nault, R. L. 1970. Ultrastructure of plant leaf tissue infected with mite-born viral-like particles. Proc. Elect. Micros. Soc. Am. 28:178-179.

5. Çağlayan, K., Medina, V., Gazel, M., Serçe, Ç. U., Serrano, L., Achon, A., Soylu, S., Çalışkan, O., and Gümüş, M. 2009. Putative agents of fig mosaic disease in Turkey. Turk. J. Agric. For. 33:469-476.

6. Çağlayan, K., Medina, V., Yiğit, A., Kaya, K., Gazel, M., Serçe, Ç. U., and Çalışkan, O. 2009. Transmissions of Fig Mosaic agents by the eriophyid mite, Aceria ficus Cotte (Acari: Eriophyidae). J. Plant Pathol. 91:235.

7. Condit, I. J., and Horne, W. T. 1933. A mosaic of the fig in California. Phytopathology 23:887-896.

8. Ebeling, W., and Pence, R. A. 1950. A severe case of an uncommon type of injury by the fig mite. Bull. Calif. Dep. Agric. 39:47-48.

9. Elbeaino, T., Digiaro, M., Alabdullah, A., De
Stradis, A., Minafra, A., Mielke, N., Castellano, M. A., and Martelli, G. P. 2009. A multipartite single-stranded negative-sense RNA virus is the putative agent of fig mosaic disease. J. Gen. Virol. 90:1281-1288.

10. Elbeaino, T., Digiaro, M., De Stradis, A., and Martelli, G. P. 2006. Partial characterization of a closterovirus associated with a chlorotic mottling of fig. J. Plant Pathol. 88:187-192.

11. Elbeaino, T., Digiaro, M., De Stradis, A., and Martelli, G. P. 2007. Identification of a second member of the family Closteroviridae in mosaic-diseased figs. J. Plant Pathol. 89:119-124.

12. Elbeaino, T., Digiaro, M., De Stradis, A., and Martelli, G. P. 2009. Complete nucleotide sequence of four RNA segments of fig mosaic virus. Arch. Virol. 10.1007/705-9509-3.

13. Flock, R. A., and Wallace, J. M. 1955. Transmission of fig mosaic by the eriophyid mite Aceria ficus. Phytopathology 45:52-54.

14. Gattoni, G., Minafra, A., Castellano, M. A., De Stradis, A., Boscia, D., Elbeaino, T., Digiaro, M., and Martelli, G. P. 2009. Some properties of Fig latent virus 1, a new member of the family Flexiviridae. J. Plant Pathol. 91:543-552.

15. Gençer, N. S., Coşkuncu, K. S., and Kumral, N. A. 2005. Bursa ilinde incir bahçelerinde görülen zararlı ve yararlı türlerin saptanması. OMÜ Zir. Fak. Dergisi. 20:24-30.

16. Gergerich, R. C., Kim, K. S., and Kitajima, E. W. 1983. A particle of unique morphology associated with a disease of rose in Northwest Arkansas. Phytopathology 73:500-501.

17. Kim, K. S., and Martin, E. M. 1978. Virus-like particles associated with yellow ring spot of redbud. Phytopathol. News 12:119.

18. Kumar, P. L., Duncan, G. H., Roberts, I. M., Jones, A. T., and Reddy, D. V. R. 2002. Cytopathology of Pigeonpea sterility mosaic virus in pigeonpea and Nicotiana benthamiana: Similarities with those of eriophyid mite-borne agents of undefined aetiology. Ann. Appl. Biol. 140:87-96.

19. Martelli, G. P., Castelleano, M. A., and Lafor- tezza, R. 1993. An ultrastructural study of fig mosaic. Phytopathol. Mediterr. 32:33-43.

20. Medina, V., Rodrigo, G., Tian, T., Juarez, M., Dolia, V. V., Achon, M. A., and Falk, B. W. 2003. Comparative cytopathology of crinivirus infections in different plant hosts. Ann. Appl. Biol. 143:99-110.

21. Mielke, N., and Muehlbach, H. P. 2007. A novel, multipartite, negative-strand RNA virus is associated with the ringspot disease of European mountain ash (Sorbus aucuparia L.). J. Gen. Virol. 88:1337-1346.

22. Nolasco, G., and de Sequeira, O. A. 1991. Double strand RNA (dsRNA) associated with fig mosaic disease. In: Proc. Portuguese-Spanish Biochem. Congr., 4th, Lisbon 5:P2-Mo.

23. Oldfield, G. N. 1970. Mite transmission of plant viruses. Annu. Rev. Entomol. 15:343-380.

24. Özalp, M. O., and Heper, E. 1972. Ege bölgesi incir mozayik virüsü ve bu virüse dayanıklı incir ağaçları üzerinde araştırmalar. Bitki Kor. Bült. 12:228-262.

25. Roland, J. C., and Vian, B. 1991. General preparation and staining of thin sections. Pages 1-66 in: Electron Microscopy of Plant Cells. J. L. Hall and C. Hawes, eds. Academic Press, New York.

26. Serrano, L., Ramon, J., Segarra, J., Medina, V., Achon, M. A., and Lopez, M. 2004. New approach in the identification of the causal agent of fig mosaic disease. Acta Hortic. 657:559-566.

27. Swofford, D. L. 1993. PAUP: Phylogenetic Analysis Using Parsimony, Ver. 3.1.1. Smithsonian Institution, Washington, DC.

28. Thompson, J. D., Higgins, D. G., and Gibson, T. J. 1994. CLUSTAL W: Improving the sensitivity of progressive multiple sequence alignment through sequence weighting, positionsspecific gap penalties and weight matrix choice. Nucleic Acids Res. 22:4673-4680.

29. Walia, J. J., Salem, N. M., and Falk, B. W. 2009. Partial sequence and survey analysis identify a multipartite, negative-sense RNA virus associated with fig mosaic. Plant Dis. 93:4-10. 